NBER WORKING PAPER SERIES

\title{
INTERNAL AND EXTERNAL LABOR MARKETS: A PERSONNEL ECONOMICS APPROACH
}

\author{
Edward P. Lazear \\ Paul Oyer \\ Working Paper 10192 \\ http://www.nber.org/papers/w10192 \\ NATIONAL BUREAU OF ECONOMIC RESEARCH \\ 1050 Massachusetts Avenue \\ Cambridge, MA 02138 \\ December 2003
}

This paper formed the basis of Edward P. Lazear's Adam Smith Lecture to the European Association of Labor Economists, Seville, Spain, September, 2003. It is a substantially revised version of a paper previously circulated under the title "Ports of Entry." The paper is part of the project "Pay and Promotion in Swedish Private Industries 1970-1990," which is under the leadership of Eva M. Meyersson Milgrom and is financially supported by the Swedish Council for Research in the Humanities and Social Sciences. We thank the Swedish Employers' Federation for access to their data. We thank Eva M. Meyersson Milgrom for help accessing and understanding the data. We thank Gerald Oettinger and seminar participants at NBER and the 2003 AEA meetings for comments. Financial support to Lazear from the National Science Foundation is gratefully acknowledged. The views expressed herein are those of the authors and not necessarily those of the National Bureau of Economic Research.

(C)2003 by Edward P. Lazear and Paul Oyer. All rights reserved. Short sections of text, not to exceed two paragraphs, may be quoted without explicit permission provided that full credit, including (C) notice, is given to the source. 
Internal and External Labor Markets: A Personnel Economics Approach

Edward P. Lazaear and Paul Oyer

NBER Working Paper No. 10192

December 2003

JEL No. M5

\section{ABSTRACT}

Internal labor markets are those where workers are hired into entry level jobs and higher levels are filled from within. Wages are determined internally and may be quite free of market pressure. External labor markets imply that workers move somewhat fluidly between firms and wages are determined by some aggregate process where firms do not have significant discretion over wage setting. There are a number of theories that lead to internal labor markets. Using data from Sweden from the late 1980s, it is found that although there is significant evidence of internal promotion being important, a significant external market exists that affects both wage setting and hiring patterns. Even in Sweden, which most would not choose as the best example of a free labor market, external factors seem to create strong discipline on the ability of firms to set wages.

Edward P. Lazear

Graduate School of Business

Stanford University

Stanford, CA 94305

and NBER

lazar@stanford.edu

Paul Oyer

Graduate School of Business

Stanford University

Stanford, CA 94305

and NBER

pauloyer@stanford.edu 
How fluid are labor markets? Most economists believe that fluidity of labor markets is a necessary condition for competition to prevail. Without at least the potential for significant mobility across firms, the concern arises that workers will be locked into their firms and as a result, may be subject to exploitation.

Indeed, Adam Smith worried about this exact issue. He argued that scarcity of labor would break any hold that employers had over their workers and would thereby eliminate their power to hold wages down. Smith wrote, ${ }^{1}$

\begin{abstract}
"The scarcity of hands occasions a competition among masters, who bid against one another in order to get workmen, and thus voluntarily break through the natural combination of masters not to raise wages."
\end{abstract}

There are two kinds of fluidity that are of issue in modern labor markets - ex ante and ex post. "Ex post fluidity" (by which we mean fluidity of the labor market for workers with at least a fair amount of tenure at a given firm) relates most closely to internal labor markets. Because workers eventually tend to settle down and remain with a particular employer for a significant fraction of their careers, the pattern of early mobility, coupled with later stability, may reflect the importance of internal labor markets, where workers are hired into "ports-of-entry" and higher level positions are filled from within. ${ }^{2}$ A variety of factors could account for such a lack of mobility, including firm-specific human capital, incentive structures, or pure institutional factors.

\footnotetext{
${ }^{1}$ Adam Smith (1776), Book I, Chapter VIII.

${ }^{2}$ See Hall (1982) on the age/stability relationship.
} 
One potential implication of ex post rigidity is that wages do not move with the market.

"Ex ante fluidity" refers to the flexibility of labor markets for workers at the start of a career. Even if strong internal labor markets exist, it may well be the case that labor markets are competitive at the time of hire into the entry level position. For example, before a worker signs on with a firm and has acquired firm-specific skills, he or she may have many choices across firms, and the ability to join a number of different firms would have implications at least for the expected present value of lifetime wages that a firm would have to offer at the entry point. But it is also possible that there is a lack of fluidity even at the entry level. For example, in a heavily unionized country or industry, hiring may be determined in large part by union rules that make it difficult for certain individuals to obtain specific jobs. Often, the rules relate to seemingly sensible job-related factors such as skills, but it is also possible that such constraints may simply be instruments that unions use to create monopoly rents for the members. Government restrictions, such as minimum wages, may also be important at the entry level.

The personnel economics approach is most useful at shedding light on ex post fluidity. Personnel economics is a sub-discipline that uses the tools of economic theory and econometrics to examine issues that are of interest in the human resources arena. Much of the literature has focused on internal labor markets and on the structure of compensation within firms. The theories and approach of that literature will be of direct applicability in analyzing labor market fluidity.

Before proceeding, it is important to point out that an external labor market that results from a fluid labor environment is not the same as an efficient market. For example, suppose that the government were to set a minimum wage well above the level that would prevail in an 
unfettered competitive market. There might be complete mobility between firms, and competition among firms would prevent any single firm from setting wages that were out of line with the market. But the resulting use of labor would not be efficient. Instead, it would suffer from distortions caused by the minimum wage. Strong centralized union wage setting could create similar inefficiencies, even if there were competition between firms for labor. As such, it is better to talk about external and internal labor markets than about competition and efficiency.

The question that is posed in this paper is narrower than whether wages and labor markets are competitive. The analysis asks whether positions are frequently filled from outside the firm or whether they must be filled by incumbents, except at the firm's ports-of-entry. Second, the analysis aims to determine how much discretion firms have in wage setting. If labor markets were truly internal, there would be no automatic connection between the wages in one firm and the wages in another, even for the same job.

Using data from Sweden, it is found that labor markets are "fluid" in two senses. First, at every level of the firm's hierarchy, a significant fraction of positions are filled from the outside. Despite institutional limitations on firing workers, there is enough turnover so that the typical firm can and does go to the external labor market to fill positions. Second, wages are determined primarily by factors that are exogenous to the firm. At least in the long run, the wages paid by the typical firm are determined by prevailing wages in the market, not by conditions in the firm. In the short run, firm effects are most important, but over the longer haul, market considerations discipline the ability of firms to set wages. Once again, this does not imply efficiency, because the "market" wage might well be determined in an institutional and non-competitive manner. But it does imply that the firm does not have significant power to exploit workers relative to the 
market.

This result is somewhat surprising, particularly in a country like Sweden where wage setting occurs in large part in a formal and institutional way. Of course, were wages completely determined centrally, at least the wage results would be less of a surprise. Centralized wage setting would guarantee that firms' wages paralleled the market. But this is not the whole story. Although $82 \%$ of individual worker wages can be explained by job, region, firm and year effects, the other $18 \%$ is worker specific variation. The firm variable only accounts for about one percent of the variation in wages among workers Thus, in the presence of significant idiosyncratic wage setting, the market wage for the job is more important than the firm in determining the long run wage level.

The conclusion is that even in the European environment where wage and employment determination are constrained by institutional factors, external labor markets are prevalent and forceful. Although promotion from within is the rule at most higher level positions in most firms, positions are often filled from outside the firm, and the wages paid are those determined by the general market conditions, not by the firm.

\section{Ports-of-Entry, Promotion and Wage Setting}

Three factors bear on the importance of internal labor markets and ex post fluidity. They are the hiring process, the promotion process, and the pattern of wage setting. If an internal labor market exists, then there must be some jobs, presumably at high levels, that are filled almost exclusively through internal promotion and there must be other ports-of-entry jobs, presumably 
at low levels, that are filled through external hiring. ${ }^{3}$ The existence of ports-of-entry is not a sufficient condition for insulated labor markets, however. Even if workers were hired only into the lowest level job in the firm and stayed in the same firm their entire lives, and even if all higher positions in the firm were filled through promotion from below, it is still possible that an external labor market for labor could prevail at all firms. Consider the most extreme case, where all firms are identical and all human capital is completely general. Once hired into a firm, there is no reason for a worker to move to any other firm. Promotions reflect changes in human capital, but workers need not be locked into the firm. Any attempt to exploit a worker by forcing him to accept a wage below the market wage would result in turnover. Such events might never be observed in equilibrium, however, because firms understand that they have no market power over the worker and always pay the competitive wage.

It is therefore necessary to complement the information on promotion with an analysis of wages. If all markets are external labor markets, then all wages should move together once job and skill have been sufficiently well defined. A change in the market wage should be reflected in a complete and parallel change in the wage of workers at any given firm. Thus, by examining the sensitivity of wages to the "benchmark" spot wage, it is possible to assess whether firms' behavior is consistent with spot or internal labor markets. Wage movements that are parallel for parallel jobs are a necessary, but not sufficient, condition for spot labor markets. Wages may move together even if firms set up internal labor markets. Consider another extreme example. Suppose that all firms are identical, that all firms set up long term contracts with their workers

${ }^{3}$ The notion that there may be ports-of-entry dates back at least to Reder's (1955) analysis of job ladders and received additional attention in Doeringer and Piore's (1971) book on internal labor markets. 
reflecting some relationship-specific value (such as specific human capital, union contracts, or implicit lifetime incentive contracts), and that some exogenous shock changes the optimal structure of the lifetime wage profile. Because all firms are identical, all firms will change their profiles in exactly the same way so that wages at any given job will move in parallel. Yet an internal labor market exists in that if a worker were to leave his current firm, he would not be able to receive the same wage at a new firm because it is only his initial firm that has an implicit contract to repay him for the loan that he has already given to that firm.

Figure 1 summarizes how the following analysis of hiring and wages identifies the level of labor market fluidity. To the extent that evidence can be provided on both the common movement of wages and the patterns of hiring and internal promotion, light can be shed on the prevalence of spot or internal labor markets. If both wage movement is largely firm-specific and if more senior workers are primarily promoted from within, or if neither of these conditions holds, then firm conclusions can be drawn. The combination that results in the upper right corner, where wages move together but slots at the top of the firm are filled from within, rules out neither internal labor markets nor external labor markets. The lower left corner is inconsistent with both because internal labor markets require that most high level positions are filled from inside and external labor markets requires that wages move together.

Prior economic studies of how firm hierarchies evolve and of the relationship between firm and market wages have been limited by the lack of data with detailed information on the entire structure of firms. While hierarchies of individual firms have been analyzed, it is unclear how well the patterns observed in these studies generalize to the large set of firms in the 
economy. ${ }^{4}$ The following empirical analysis addresses both dimensions of Figure 1, using data that cover almost all white-collar workers at a group of firms that account for about $40 \%$ of the Swedish labor market during the 1970s and 1980s. ${ }^{5}$ It appears that the labor market is in large part competitive. Although most firms fill most high level positions from inside, almost all firms engage in a significant amount of outside hiring, even at the highest levels of the firm.

Additionally, the analysis of wage movements is most consistent with a competitive labor market, where wages for given jobs largely move together.

\section{Theoretical Background}

The simplest view of the labor market is one where all human capital is general. Then mobility could occur at every level of the firm's hierarchy and wages could reflect productivity. For example, though some universities have a comparative advantage in training assistant professors, those schools need not retain all their trainees. When assistant professors have acquired the requisite knowledge, they move to other universities and enter as associate or full professors. Human capital in academics, particularly at the research end, is general, so movement into jobs even at high levels seems natural. Long-term contracts are unnecessary and in fact have no role in this purest form. External labor markets allocate labor perfectly, and there is no reason, save mobility costs, for there

${ }^{4}$ See Lazear (1992) and Baker, Gibbs, and Holmstrom (1994) for economic studies of private sector firms. See Barnett, Baron, and Stuart (2000) for a study of a large government bureaucracy.

${ }^{5}$ Gibbs, Ierulli, and Milgrom (2002) use the same data to study factors that drive employees to move between levels, change firms, or change occupations. While both papers study across-firm and within-firm transitions, this paper considers the hierarchies and sources of workers from the firm's perspective rather than focusing on the workers' careers. 
to be any permanent attachment to a firm.

Many labor markets are not so simple, however, and a number of theories give rise to portsof-entry and to firms not needing to be perfectly responsive to market-wide wage changes. Although some of these theories involve market power by one party, most involve situations of competition at the hiring stage followed by the development of relationship-specific value. ${ }^{6}$

A classic reason for internal labor markets is firm-specific human capital, which dates back to Becker (1962). Once a worker acquires firm-specific human capital, his value inside the firm deviates from that at other firms, which creates a situation of ex post bilateral monopoly. ${ }^{7}$ The firm must offer new workers a competitive long-term contract, with a present value equal to the present value of the worker's value to the firm. At any point in time after the start of the contract, the present value of the remaining wages must equal or exceed the present value of the alternative wages obtainable. But there is no need for the firm to fully adjust workers' wages exactly to current market rates once those workers have developed firm-specific human capital.

The theory of firm-specific human capital also provides a coherent story that might allow for ports-of-entry. If high level jobs in the firm require more firm-specific knowledge than low level ones, there is no way to acquire firm-specific knowledge other than spending time in the firm. Workers are hired in at low levels and move up the hierarchy as they acquire skills. ${ }^{8}$

${ }^{6}$ One widely analyzed theory of labor market power is monopsony, which can arise from search, geographical lock in, or other causes. Though this is probably important in certain market segments, it seems unlikely to permeate the entire national labor market studied here. For a detailed analysis and summary of monopsony, see Manning (2003).

${ }^{7}$ Lazear (2003) offers another approach to firm-specific human capital that is based solely on general skills that are transferable across firms.

${ }^{8}$ Note that, while firm-specific human capital could lead to entry into certain jobs, the theory actually does not require that employees change job titles or levels. 
Another reason for long-term labor contracts where wages at a point in time deviate from outside opportunities is incentives. One version of this idea is the upward sloping experienceearnings profile (Lazear 1979), where deferred earnings provide workers with incentives to put forth effort over their careers. Firms receive their surplus early in the career by paying workers less than they are worth and pay workers back later in the career by paying them more than they are worth. Once again, there is a deviation between wage and alternatives even though, over the worklife, the present value of earnings equals the present value of productivity.

A related idea, and one that can lead to both ports-of-entry and deviations between internal and market wages, is tournaments (see Lazear and Rosen, 1981.) In tournament theory, jobs are defined as wage slots. An individual enters the firm at one job level and is promoted to another if he wins the tournament. Losers remain in the same job. There is no necessity that tasks differ in the two jobs. In fact, most of tournament theory makes little mention of tasks. ${ }^{9}$ Promotions to higher levels serve to motivate workers, so it is necessary that some workers come in at lower levels. The model taken literally implies that the top level of the firm can only have workers who are promoted because it serves no role other than to motivate those one level below. Although the market is competitive, there is no direct connection between wage and worker output.

Worker-firm matching provides another framework in which worker wages can deviate ex post from market wage offers. In Jovanovic (1979), the productivity of any worker/firm pair (or "match") is idiosyncratic. If a match is sufficiently good, the worker is worth more to the current firm than to outsiders and bilateral monopoly exists as the result of rents. Again, worker wages can

\footnotetext{
${ }^{9}$ One exception is Gibbs (1995), who looks at tournaments that perform a sorting role.
} 
deviate from market alternatives. ${ }^{10}$

Pure search offers yet another reason. If there is a distribution of wages that exists purely as a result of search costs, then some workers who are fortunate to find a firm that pays high wages will not automatically have attractive alternative wage offers. ${ }^{11}$ The search model and the matching model neither require nor preclude ports-of-entry.

Finally, purely institutional factors can create wedges. A union that negotiates high wages might create an environment where workers cannot readily obtain alternative employment at the same wage. Alternatively, suppose workers are perfect substitutes for one another and that they rise within organizations based only on seniority, nepotism, influence, and discrimination. Thus, all workers must come in at the bottom and acquire promotions by working the system for a long enough period of time. In such a world, wages need not move very closely with market wages and firms will have specific ports-of-entry. Note, however that this view allows little role for markets and mobility. Firms that run their businesses in an arbitrary fashion can be supplanted by those that behave more rationally. Only when firms (rather than just their workers) are very insulated from market forces could such a system persist.

\section{The Data}

In much of the analysis that follows, the focus is on a "job" or occupation. In order to study

\footnotetext{
${ }^{10}$ There are a number of variants on this model. Waldman (1984) is a well-known example that focuses on the importance of private information.

${ }^{11}$ Alternatively, employer search costs can create differences between wages paid by a given firm and the external labor market wage needed to hire a worker. See Lindbeck and Snower (1986).
} 
transitions between similar jobs at multiple firms or to determine how market-wide wages for a job affect the wage for that job at an individual firm, it is necessary to have very detailed and consistent data on jobs across a large sample of firms. While data of this sort do not exist for the United States, there are a number of matched employer-employee datasets from European countries. ${ }^{12}$ The data in this study come from Sweden. The data were collected and provided by the Swedish Employers' Confederation (SAF). ${ }^{13}$ The SAF assembles very detailed and uniform data from establishmentlevel personnel records. The firms span virtually every private sector industry (with the exception of financial services). This study uses the SAF data for white-collar employees. In any given firm, the data includes all white-collar workers, with the exception of the CEO and other members of the executive team who negotiate their own wages rather than letting a union negotiate on their behalf. Years of coverage are 1970-1990, inclusive. During that time, the data were used in annual wage negotiations and were monitored by SAF and the relevant labor unions. Therefore, data quality is very high and is likely to be much more accurate than standard surveys that rely on self-reported wages.

The dataset's firm and establishment characteristics include industry code, number of employees, and region. Individual data include wage, age, gender, and a detailed occupation code. The wage measure used in this study is base wage and refers to the normal pay for a 38-hour work

\footnotetext{
${ }^{12}$ The Census Bureau has been engaged in an ambitious project to develop matched employer-employee matched data. This data has been used in numerous studies (see, for example, Abowd, Haltiwanger, Lane, and Sandusky, 2001) and has several features not generally available in the European datasets. However, there is no detailed information on jobs so it is impossible to examine the wage structure or promotion paths within firms.

${ }^{13}$ This data description borrows liberally from Meyersson Milgrom, Petersen, and Snartland (2001). See that paper for further details about the SAF data.
} 
week.

The occupation code, which is part of the Swedish occupational coding system and is known as the "BNT" code, is a four-digit number that can be thought of as the person's job title or "job." The first three digits of the occupation code, which is referred to as an "occupation family" throughout this paper, determine the type of work the person does. There are 51 unique white-collar occupation families.

The fourth digit of the occupation code, which is referred to as "level" throughout this analysis, is a single digit that indicates the individual's degree of responsibility and skill. In the analysis that follows, "level" can take a value between 1 (lowest level) and 7 (highest level). In some of the analysis, some of the levels are combined, but levels are always normalized so that the lowest level at any given firm is one. Not all occupation families have seven levels, so the 51 occupation families have a total of 285 occupation/level combinations.

Figure 2 shows the distribution of workers among these levels, as of 1988, at those firms that have at least six of the possible seven levels. The bottom level is not the largest level. Rather, the bottom few levels are quite small. As will be shown below, most employees skip the bottom levels. Furthermore, there is no single level that serves as a port of entry. There are many different entry and promotion paths that exist in Swedish firms. Figure 3 shows the distribution of wages in 1988 for the sample as a whole and Figure 4 shows the distribution at the largest firm (which is fairly typical.) This distribution looks similar to the distribution of levels because, not surprisingly, wages and levels are correlated. It is worth noting that wages and levels are far from perfectly correlated. Levels are determined by tasks, not by pay. However, redefining job levels to be pay levels would not materially affect the conclusions drawn below. Patterns in entry and movement among the wage 
distribution are similar to those across levels.

The exact tasks associated with each level for any given occupation are documented in significant detail and, to the degree possible, are applied consistently across firms. Unions and the SAF oversee this classification. Because the data are used in wage negotiations, both sides have an incentive to insure the integrity and comparability of the classifications.

These data have the advantage of covering many years and many different sizes of companies. While that allows relatively general conclusions, it also presents numerous challenges. First, not all firms have workers at each level and, even at those that do, some of the firm/level observations are quite small. As a result, for some of the analysis, firms will be separated by the number of levels represented at the firm. In other parts, analysis will focus only on firms with some employees at one or both of the two highest levels and one or both of the two lowest levels. Finally, when sizeable firm/job groups are necessary, only the 100 largest firms in the data are examined.

A second challenge is that, as a result of changes of ownership, data entry problems, or other causes, there appear to be some false transitions in the data. For example, there are cases where a firm with many employees is in the data in year $t$ but not year $t+1$. In year $t+1$, another firm with largely the same individual workers appears in the data for the first time or a firm that has been in operation for several years before year $t$ adds most of the employees from the firm that disappeared. In an attempt to maximize the length over which individual workers are followed and to minimize miscoded turnover, a variable called "family" is generated. Any two firms where more than half the workers from one firm appear at the other firm in the next year are treated as being part of the same family. If firms $x$ and $y$ and firm $y$ and $z$ are in the same families, a family is created including all three of these firms and any other firm that has a family relationship with any individual firm. 
Finally, though up to twenty-one years of data are available for each firm, a significant portion of the job observations are censored on one side or the other. In some of the analysis, the level at which a person entered the firm for which he works is important. This information is not available with certainty for many of the jobs observed. When relevant, the implications of this censoring are considered in the discussion of the results.

\section{Empirical Analysis of Ports-of-Entry}

\section{A. Entry Level and Promotion}

The first analysis considers the fraction of workers in a given level (as of 1988) at a given firm who moved to that level from a different level in the same firm. This analysis includes all workers and all firms. There are seven possible levels, but not all firms have employees at each level. Each column in Panel A of Table 1 corresponds to firms that, as of 1988, had each number of levels. In this table, levels are defined by the "BNT code" in the SFA data, as described above. One problem presented by the BNT code levels, however, is that they are not necessarily comparable across occupation families. That is, a level 2 job in one occupation could actually pay more and have more responsibility than a level 3 job in another occupation. As a result, this table will make it appear that demotions are more likely than they actually are. To insure that this comparability issue does not affect our conclusions, an alternative definition of level is used in Panel B of the table, as described below.

Panel A is based on employees' 1988 level. The table shows how frequently employees had

previously been at a different level with this same employer. Employees who were already working 
in their current level when the firm first enters the dataset are dropped because how they transitioned into their 1988 positions cannot be determined unambiguously.

Panel A of Table 1 makes it clear that the rate of external hiring relative to internal hiring decreases monotonically at higher levels. For example, in firms with six or seven levels, over $80 \%$ of employees in the top three levels moved to their current level from another level in the same firm. A third or fewer of employees moved into their position internally at low levels of the organization, however.

Panel B of Table 1 uses an alternative approach to perform the same analysis. Level is defined using "Job/Wage Levels." These were determined by calculating the average wage of the $285 \mathrm{BNT}$ codes in 1988 and dividing the codes into five quintiles based on these averages. Job/Wage Level 1 jobs are those in the lowest quintile of average wages, Job/Wage Level 2 jobs are in the second lowest quintile, etc. As in Panel A, the levels displayed in the table are actually level relative to the lowest level at the firm. 3,568 of the firms in the sample employ workers that all fit into one of these Job/Wage Levels. However, nearly $40 \%$ of the workers at these firms previously held a position in another Job/Wage Level at their 1988 employer.

Though the definition of level in Panel B is very different from the definition in Panel A, the conclusions are almost identical. At higher levels, the firm is more likely to fill positions internally. However, at all Job/Wage Levels, a large set of employees are hired externally.

Table 1 provides evidence that there are large differences in inside and outside hiring by level. The lower levels in the typical firm are much more likely to hire from the outside; the upper levels are more likely to hire from within. This is consistent with the notion that there are ports-ofentry into the firm. Note, however, that even at the very high levels, a significant fraction of workers 
are hired from the outside. In firms with the most levels (which hire the fewest from the outside at top levels), approximately $12-15 \%$ of those in the highest level were hired directly from outside the firm.

As shown in Figure 2, the fourth level from the top - and not the bottom level - is the largest in terms of number of employees in both 6 and 7 level firms. Still, a relatively large proportion of the workers in this modal position come in through promotion. (Note that $65 \%$ are hired into the modal position internally.) Thus, it appears that the middle levels are almost absorbing states; most workers either get hired directly into these levels and stay there or get promoted from lower levels to the middle levels and rarely move beyond.

While Table 1 examines whether employees move into each level internally or externally, Table 2 looks at where workers start in the firm relative to where they are at a given point in time. To maximize the number of firms included in this analysis, the top two levels are combined and the bottom two levels are combined. Firms that do not have workers in both the top and bottom (combined) levels are dropped.

The second and third columns of Table 2 report the median and mean ratio of the number hired into a level to the number in that level, where the unit of observation is a level within a firm. Thus, the median is the ratio of the $50^{\text {th }}$ percentile firm ranked by (\# hired into level) / (\# in level in 1988). For example, at level 4, a median of .50 is reported. This implies that in the median firm, half as many workers were hired into level 4 as are currently found in level 4 . The numbers are higher at lower levels where more are hired in, relative to those who are still at that level. The fourth column reports the number of firms in the sample at each level. The fifth column is the number in the level at each firm, averaged across all firms. "Cum. hired" is the number hired in that level or 
below. "Cum. in level" is the total number in that level or below. The last two columns are the same values expressed as percentages, i.e., the cumulative distributions.

The last two columns highlight the difference between entry level and current level. Fiftynine percent of the workers are hired in at one of the bottom two levels but only $31 \%$ worked in those levels in 1988. The modal hiring level is 2 while the modal employment level is 3 . At the lowest level, the median firm has twice as many hired into level 1 as actually are employed at that level. The highest level is almost the mirror image of the bottom with the median firm employing $2 \frac{1}{2}$ times as many at that level as it hired in at that level. In summary, many more work in the top level than are hired into it and many more are hired into the bottom level than work in it.

Table 3 displays three transition matrixes from entry level to 1988 level, focusing on the same five levels as in Table 2. Panel A displays the source of workers in 1988, regardless of changes in "occupation families", while Panel B looks only at transitions of workers who move up and down within a single occupation. Panel $\mathrm{C}$ focuses on employees with at least ten years of service at their 1988 employer. Panels A and B lead to similar conclusions, so we focus our discussion on Panel A. The longer tenure employees in Panel C generate slightly different conclusions, as discussed below.

Even for the highest level workers, more workers who are currently at level 5 entered at level 5 than at any other single level. Of course, those who definitely entered at level 5 comprise less than a quarter of those at that level, but it is clear that despite the existence of lower level entry and 
upward mobility, entry from outside the firm is reasonably common, even at the top levels of the typical organization. ${ }^{14}$

The summaries under each panel provide a sense of the overall pattern of entry and mobility. They compute the number and proportion of individuals along the diagonal, in the lower triangle and in the upper triangle of each matrix. Employees with unknown entry levels are excluded from this calculation. First, $52 \%$ of the Panel A observations lie along the diagonal, which means that 52\% of the individuals in the typical firm are currently at the same level as they entered. It is striking that $46 \%$ are in the lower triangle, which means that $46 \%$ have been promoted at least one level. Only $2 \%$ lie in the upper triangle, implying demotion (often due to changing occupation). Thus, entry at levels lower than those currently held is a very common pattern.

The picture that emerges from Tables 2 and 3 is that most individuals at any given firm were hired into lower or middle levels of the firm and did some advancing to higher levels. Almost 90\% of the typical firm's workers were hired into levels 1,2 , or 3 . About $85 \%$ work in those three levels at any point in time. It is the middle levels of the firm that comprise most of the workforce. The lowest level is relatively small.

Even though disproportionately many are hired into the lowest levels, a substantial fraction of the workforce makes its entry by being hired into the middle levels of the firm. The modal worker entry/current combination in Table 3 is the 3,3 cell. The second biggest cell is the 2,2 cell. The number who enter at 2 and are promoted to higher levels exceeds the number who are hired into

${ }^{14}$ Strictly speaking, the current level is the modal entry level among those observations where the entry level is known. Left censored observations are less likely to have entered in the current level. As a result, at the highest levels, the current level may not be the true modal entry level. 
and remain at level 2. Thus, the most important levels in the typical firm in terms of number of employees also happen to be ports-of-entry, accounting for most of the hiring. These levels are both jumping off points and destination jobs for a large part of the workforce.

Firms do not appear to have ports-of-entry in the standard sense. Most workers do not enter at the bottom. For example, those who are currently in level 5 come in roughly even numbers from levels 3,4 , and 5, but rarely from the two lowest levels. Those who are currently at level 4 are most likely to have entered at level 3 , then level 4 . The general picture is that workers enter at or near the position that they currently hold. While some of these workers may still be promoted at some point in the future, Table 3 provides a picture of internal and external transition from the firm's point of view. For example, the $(3,2)$ entry in the table, equal to 11,333 , is large relative to the total in that row. About two-fifths of the workers who are employed at level 3 in 1988 and for whom the entry level is known entered at level 2. But it is also true that a slightly larger number $(12,469)$ who entered at level 2 are still at level 2. Although some may eventually move up to level 3, it is clear that at a point in time, many workers remain at the level at which they were hired into the firm.

It may not be sufficient, when looking at transitions within firms, to use the entire sample of workers at any given point. Many workers have recently entered their firm and will not have been promoted at this point, while many others will only work for their current firm briefly. In order to focus on workers more likely to have moved within their current employer Panel C of Table 3 shows the same analysis as Panels A and B, but limits the sample to workers who have been with the firm for ten years or more. The picture changes somewhat, but the conclusions are remarkably similar. There is still a significant portion of the workers along the diagonal. About one-third of the workers remain in the job levels into which they were hired. A small fraction are demoted and almost two- 
thirds of the workers have obtained at least one promotion during their time at the firm. Thus, entry with promotion is the most common pattern, but a sizeable fraction are hired into the job that they will hold, perhaps for their entire lives. ${ }^{15}$

More can be understood by learning about the kinds of jobs that are represented by lowest and middle levels. The appendix provides descriptions of typical jobs in the data by major occupation. The occupation families are chosen to be among the largest numerically in the data. In one occupation family (manufacturing), there are no level 1 jobs. In construction and marketing, the lowest level jobs are for workers who do the most mundane tasks. For example, in construction, a job that requires simple calculations regarding dimensions and materials is classified as level 3 (out of 7). Most white-collar workers in construction are likely to be required to do some of these simple calculations, which means that firms hire most of their basic white-collar workers into levels 3 or higher. But the relationship is far from obvious because in both manufacturing and construction, any worker at level 3 or above is required to have a number of subordinates, which would suggest that there would be more below than at this level. Part of this may have to do with the data being restricted to white-collar workers. In manufacturing in particular, the subordinates might be blue-collar workers who do not show up in these data and therefore make the bottom of the hierarchy appear narrower than it is.

Table 4 reports time in job. This is defined as number of years an employee stays in a particular job (that is, 4-digit BNT code.) Employees who get promoted up a level, change occupation families, or change firms are defined to be taking a new job. Note that, because of the nature of the data, this is reported separately for jobs that start and end within the time the firm is

\footnotetext{
${ }^{15}$ One change is that in levels 4 and 5, the modal level of hiring is now level 3.
} 
in the sample ("uncensored"), jobs that end during the sample but were already in progress when the firm first enters the sample ("left censored"), jobs that begin during the sample but are still in progress when the firm leaves the sample ("right censored"), and jobs that are censored on both sides.

Table 4 demonstrates that the lowest levels in the firm tend to have the shortest job tenures. ${ }^{16}$ Low level jobs are common entry points, but they are also common exit points. Note that the average tenure (uncensored) in level 1 jobs is about half that in level 5 jobs. The same pattern holds, but to a lesser extent in the censored data. So workers do not spend much time in low level jobs. At least on average, they move to higher level jobs in the firm or they leave the firm.

The more interesting and perhaps surprising finding in Table 4 is that job tenure becomes fairly constant above the lowest two levels. Average job tenures do not differ much among the top three levels. Job tenure increases slightly at each increasing level until the highest level, when it drops slightly. This suggests that many employees have long spells in middle levels of the typical firm. It does not appear that firms are enforcing "up or out" policies, nor that employees who do not get promoted regularly leave to seek better opportunities. Rather, it seems many workers settle into a long spell in middle and upper-middle levels. This is more evidence that middle levels of the firm act as semi-absorbing states.

While Table 4 provides a sense of how often transitions take place, Table 5 breaks those transitions down into internal and external movement. The table reports average entry rates to and

${ }^{16}$ Many previous papers equate the term "tenure" with time spent at a given company. Here "job tenure" is defined as tenure in a job (that is, occupation family-level combination) at a single firm. An employment spell at a single employer can be made up of several jobs, each with its own job tenure. 
exit rates from a given firm/job. As in Tables 3 and 4, the top two levels are combined and the bottom two levels are combined. Also, the sample is restricted to firms that have employees in the top and bottom of the five possible levels.

Panel A of Table 5 analyzes the entire sample. Each person/year is an observation. For example, of all the individuals in level 3 as of year $t, 10.03 \%$ worked in a different firm in year $t$ 1 and $13.03 \%$ worked at another job in the same firm in year $t-1$. Also, $8.79 \%$ of the workers in level 3 as of year $t$ worked at another firm in year $t+1$ and $10.75 \%$ worked in a different job at the same firm in year $t+1$.

At lower levels of the typical firm, external entry is common while internal entry is not. At high levels, there is much less external entry. Similarly, it is very common for employees at the lowest levels to move to another job within the firm. This internal exit becomes less common at each increasing level within the firm.

The pattern in external exit is interesting and somewhat surprising. Leaving the firm is less common at the first few movements up in levels. However, only the levels 1 and 2 difference in external entry is meaningful, as turnover is about one-fourth less common for level 2 workers than for level 1 workers. Turnover is fairly stable for level 3 and 4 workers, relative to level 2. However, workers at the top level are actually significantly more likely to leave their firm than workers at any level other than the bottom. Combined with the results for level 5 in Table 4, it appears that the top levels of the white-collar Swedish labor market are somewhat more fluid than middle levels.

Panel B of Table 5 limits the analysis to employees between the ages of 40 and 45 . For this older set of workers, the patterns are quite similar to those for the larger group. External exit rates are lower than for the bigger sample, but at least $6 \%$ leave the typical firm at every level. Even for 
these workers who are more likely to have found stable matches, turnover is higher at the highest level of the firm. Again, there appears to be a fairly robust market for senior managers.

One possible contributor to the exit rate patterns in Table 5 is documented by Holmlund and Storrie (2002). They show that there has been an upward trend in the use of temporary workers in Sweden in recent years. This is unlikely to be driving the results in Table 5 because, as Holmlund and Storrie (2002) show, the bulk of the increase in temporary workers came in the 1990s. Thus, temporary workers were not as important in the period studied here. However, to insure temporary workers are not dominating the exit rates in Table 5, the analysis was redone using only employees who had been at their firms at least three years. The exit rates are about one percentage point lower for both external and internal exits at each level and the conclusions are qualitatively similar. Were entry and exit rate analyses, such as those in table 5 repeated for the 1990s, it is possible that conclusions would be modified somewhat because of the growth of temporary employment. But the existence of temporary worker does not seem to drive the results here.

Summarizing, the middle levels of the typical firm account for most white-collar workers and the most white-collar hiring. There is a tendency for workers to be hired in at lower levels than they end up. There are ports of entry in that people tend to enter at different levels than they end up, but the extreme version of internal labor markets story does not seem to hold. A substantial fraction of workers are not hired in at the bottom, but rather at positions close to the ones they currently hold.

\section{B. Disaggregation of Firms}

Up to this point, the data has been analyzed as if it all came from one large firm. The reality is that these data represent as many as 7,267 firms. Now consider how the patterns documented so 
far vary across firms in the sample. Differences in firm size naturally generate some heterogeneity, but the rest of this section looks at heterogeneity in ports-of-entry across reasonably similar firms. The 100 firms (as of 1988) with the most employees in the sample are considered, conditional on the firm having employees at all five of the levels analyzed in Table 3.

It is possible to get at the issue using analysis of variance. Let the dependent variable be the internal hiring rate and let the unit of analysis be the job within the firm. In the sample of the 100 largest firms, each having five levels, up to 51 occupation families, and up to 252 jobs, there are 6,306 observations for this regression. How much of the variation in the internal hiring rate is due to jobs, occupation, and level and how much is due to firm fixed effects?

Panel A of Table 6 starts with a regression that includes firm and job indicator variables. Both the collection of firm fixed effects and the group of job indicators are significant as a group. That is, the hypothesis that these 100 firms have the same tendency to hire from within can be rejected, as can the hypothesis that the internal hiring rates are the same at each job in the typical firm. However, the job fixed effects are far more powerful than the firm fixed effects. The majority of job fixed effects are statistically different from the median job fixed effect, while only fifteen of the firm fixed effects are statistically significant.

Panel B of the table shows that just these five levels are responsible for much of the explanatory power of jobs. Firm, occupation family, and level fixed effects are each jointly significant, but the five level indicators explain more of the across job variation in internal entry rates than the combination of occupation and firm.

There are examples of firms that have particularly strong promote-from-within tendencies. For example, 21 of the 100 firms source at least $50 \%$ of workers in each of levels 2 through 5 from 
another level in the firm. Eight of the 100 get at least $60 \%$ of their workers internally at each of these levels, while only one firm gets at least $75 \%$ internally at each of these levels. In terms of firms showing a strong tendency to hire externally, only one firm hired fewer than $50 \%$ of its workers at every level from another level internally.

In general, while there are differences across firms, the primary influence is the level. Low levels have significant amounts of external hiring and high levels are dominated by promotion from within. Tables 1, 2, and 3 suggest that the use of promote-from-within policies are the rule among most firms and at some firms, these human resource policies dominate the hiring and promotion process. However, all the tables discussed thus far make it clear that most firms also show at least some willingness to fill positions at all levels externally.

\section{Discussion}

The data are inconsistent with the caricature version of ports-of-entry. It is clear that in the typical firm, workers are hired from outside at virtually every level. Even among the most extreme firms in terms of internal hiring, it can be said that external hiring is significant. For example, even at the highest levels, the typical large firm hires an average of $15 \%$ of its workers from the outside. But it is also true that hiring from the outside is much rarer at the top of the firm than at the bottom. The corresponding portion of those hired from the outside at level 2 is nearly seventy percent. In firms of all types (in terms of total number of levels) shown in Table 1, the pattern is the same. There is plenty of internal job filling, especially at the top of the firm, but even at the very top, every type of firm category uses external hiring.

The data also show that transition from lower to higher levels is common in most firms. 
Table 3 shows that almost two-thirds of workers who have been with the firm at least ten years move up at least one level from the level into which they were hired. Not surprisingly, entry at lower levels with promotion to higher levels is a very common practice in the typical firm. But again, at any point in time, a large number of workers are at the level into which they were hired. The snapshot analysis in Table 3 shows that even at level 5, a larger number of employees were hired into that level than into any other single level.

In general, this labor market seems to provide enough mobility for a substantial amount of competitive pressure, given that markets can be arbitraged with very little actual movement. The findings are consistent with the tournament view of the labor market, especially as supplemented by Chan (1996). Hiring into high levels of the firm is primarily from within. The higher level jobs draw most of their talent from inside in order to provide appropriate incentives, but if there is a sufficiently dominant outsider, firms hire into the position from the outside. Internal promotion is preferred to external hiring because it provides better incentives for workers at lower levels in the firm. If workers know that they must compete with a large pool of outsiders for a particular job, their incentives are diluted because the chances that their increased effort can affect the probability of winning against such a large pool of competitors are slight. If the pool is narrowed to insiders, incentives are enriched. Occasionally, however, insiders are so dominated by an outsider that it pays to hire the outsider over promoting the insiders even at the cost of diminished incentives. But such cases should be relatively rare. The pattern in the data seems consistent with this view. Furthermore, if the value of effort is higher at the top of the hierarchy, providing incentives to high level workers is especially important, which could explain why firms are reluctant to hire from the outside at top levels. 
The data are also consistent with models of firms valuing a mix of firm-specific and general human capital. Suppose that a significant fraction of human capital is firm-specific, which gives insiders an edge over outsiders. Most promotion would be from within and this would be most true at the top, where workers possess the greatest quantities of firm-specific human capital. But, occasionally an outsider comes along who so dominates insiders that it is worth hiring him even though he does not possess the firm-specific human capital of the incumbents. This interpretation, however, may be inconsistent with the homogeneity in the promotion policies and the fact that promotion-from-within policies are not highly correlated across levels within firms. That is, one might expect that there are some firms where firm-specific human capital is very important and others where it is not. In this case, the firm effects in Table 6 would be important, indicating that firms that promote from within at one level also do so at other levels. The failure to find large firm fixed effects in Table 6 somewhat undermines the human capital explanation for our findings.

Given the amount of external hiring that occurs at every level, it would be somewhat surprising to find that firms are insulated from market forces. If other firms are hiring even highlevel workers from outside, a firm would seem to be forced to meet market wages in order to retain labor. The next section looks carefully at this issue of the relationship between individual wages and market wages.

\section{The Relationship Between "Internal" and Market Wages}

\section{A. Basic Structure of Wages and Wage Changes}

The simplest way to get a sense for the effect of internal labor markets on wages is to look 
at how important firm effects are in a wage regression. Panel A of Table 7 presents results of an analysis of variance of wages on firm, occupation, region and year indicator variables. The sample is the white collar workers at the 100 largest firms in the SAF sample (as of 1988) and an observation is a person/year between 1984 and 1990. The dependent variable is log wages and explanatory variables include firm indicators, job indicators (where a job is defined to be a unique BNT code), 25 region indicators, and year indicator variables. Including firm and job effects leads to explaining a much higher proportion $(\mathrm{r}$-square $=82 \%$ ) of the variation than in a typical wage regression, even though the explanatory variables do not include demographic characteristics.

Year and occupation account for the bulk of explanatory power. Although there are almost three times as many occupation categories as firms, occupation accounts for almost 100 times as much of the variance as firm and an even higher proportion than region. Jobs matter, therefore, in a consistent way across the market. Wage levels are in large part dictated by occupation, at least in the cross section. This finding is consistent with a spot labor market where wages are determined by the market at the level of the job.

The result is also consistent with centralized wage setting, where firms have no discretion over wages paid once they have been centrally set. As long as firms were free to hire from the outside, this would not be inconsistent with the view that firms buy in an external labor market, albeit a wage-administered rather than competitive one. However, even this view is not quite accurate. The ANOVA on wage levels shown above reveals that even holding detailed job constant, the r-square is $82 \%$, implying that $18 \%$ is left unexplained. Also, as shown below, there is important 
short-term variation in wages by firm that does not reflect centralized wage bargaining. ${ }^{17}$

However, collective agreements are clearly important because, though firm effects matter, the explanatory power of the regression barely changes when firm effects are removed. The r-square falls to $81.24 \%$. Given that the job is the unit of negotiation in centralized wage bargaining, it seems that firms exert some, but not a great deal of, discretion in setting wages, at least over the long run where wage levels are effective. Below, it will be shown that firms do have significant discretion in setting wages in the short run.

Figure 5 provides a graphical representation of wage variation within occupations. The figure shows kernel density estimates of 1988 wages for all workers in one of the largest occupation families - construction. As the figures shows, there is some heterogeneity across levels in wages and there is considerable overlap in the ranges of wages for each of the neighboring levels.

The results for wage changes are different. Panel B of Table 7 reports the corresponding analysis of variance for wage changes. Once again, time effects are key. There are high raise years and low raise years. But now, firm effects become more important than occupation effects. Apparently, over the short run, firms can adjust wages in ways that take into account their own idiosyncratic situation. But over the long run, as reflected in wage levels, they must bring them into line with other wages in the occupation in order to meet competitive pressure.

In some sense, the result is obvious. Engineers are likely to earn significantly more than secretaries even if both happen to have been in the same firm during the same period. The firm effects that exert an influence on raises in the short run cannot be expected to alter the entire

17"Wage drift," as it is termed in Sweden, refers to wages that drift upward above the level determined by centralized wage bargaining. 
structure of wages in any significant sense. The basic pattern of occupational wage differences would be expected to prevail, despite the short-run importance of firm effects.

\section{B. Discussion}

As demonstrated by Figure 1, neither the results on wage determination nor the results on entry taken independently are sufficient to draw definitive conclusions about the prevalence of internal or external labor markets. But the evidence on both wages and internal and external hiring patterns rules out pure internal labor markets. There is significant outside hiring at higher levels in the typical firm and there is clearly co-movement of wages, as reflected in the ANOVA results. There is considerable promotion and filling of jobs at higher levels from within. Internal mobility

plays a significant role in filling higher level jobs in all firms. However, a non-trivial fraction of workers are hired from the outside even at the highest levels in the typical firm. Furthermore, there is no evidence of a unique pattern of entry and movement within firms. Most workers who end up at relatively high levels in the firm were hired in at a high level. Those workers who are hired in at very low levels of the firm do not account for the bulk of workers at the higher level of the typical firm.

Wages do exhibit significant co-movement within occupation. Although there are important firm-specific variations in the size of raises from one year to the next, the wage level regressions imply that adjustment over the longer term results in wages that are very much in line with an external labor market. This evidence is also consistent with a market that is disciplined by external forces (at least over the long run). In the shorter term, it appears that firms have some discretion over wage setting. 


\section{Entry and Exit Rates}

Most of the discussion has been in terms of firms being able to hire from the outside. To the extent that firms hire from the outside, then it would appear that workers can obtain jobs even at high levels in other firms. Although this may not be as common as obtaining a high level job in one's own firm, the fact that hiring from the outside is common means that there is pressure on the a worker's current firm to keep pace with the market in order to retain workers.

Another constraint may be the ability of firms to fire workers. This also creates a deviation from what is normally thought of as a functioning external labor market. Were firms prevented from firing workers, there would be less hiring from the outside and the workers would be somewhat insulated from the market. This does not imply that their wages would be protected. It is the coupling of job protection with wage protection that creates the problem for employers because allowing employers sufficient discretion over wages would be tantamount to allowing them to terminate their workers. By offering a low enough wage, the worker could be induced to quit.

Given the centralized bargaining and importance of job effects discussed above, it is likely that employers do not have such discretion over workers' wages. It is therefore instructive to look at generalized labor turnover.

Table 5 provides results that speak to this issue. First note from panel A that almost $12 \%$ of the jobs that exist in any given year in the typical firm are held by individuals who were not employed by that firm last year. Thus, the typical firm is hiring in about $12 \%$ of its labor needs every year. Furthermore, even at the highest levels of the firm, almost $7 \%$ are hired in from the outside. These facts suggest that workers do indeed have somewhere to go; they are not locked into their 
current firms. Second, the fact that $12 \%$ are hired from the outside implies that the firm must resort to an external labor market for a significant fraction of its employees.

Separation rates are also significant at the typical firm. Although these data do not allow us to distinguish between quits and layoffs, Table 5 does reveal that over $9 \%$ of the typical firms' workers leave each year. Although this number is lower than that of some other countries' labor markets, it does, coupled with hiring numbers, suggest that mobility into and out of firms is substantial, even in a highly centralized labor market as Sweden's.

\section{Conclusion}

The results on both mobility and wage setting suggest that at least over the long run, external labor market wage setting is an important force in Swedish labor markets. Although there is much promotion and job filling especially at high levels from within, there is significant hiring from the outside at all levels of the typical firm's hierarchy.

Furthermore, wage levels seemed to be accounted for primarily by occupation, especially level of the job, and time. Idiosyncratic firm-based wage movements are important over the shortrun, but in the longer term, occupation is a more important determinant of wages, suggesting that firms are disciplined to a large degree by the external labor market in their wage setting.

The results in no way imply that labor markets in Sweden are efficient and undistorted. The fact that firms must compete with each other for labor does not mean that centralized wage setting and other institutional factors do not play an important role in labor markets, perhaps distorting behavior significantly. The evidence that is presented in this paper sheds no light on this more fundamental question. 


\section{References}

Abowd, John M., John Haltiwanger, Julia Lane, and Kristin Sandusky."Within and Between Firm Changes in Human Capital, Technology, and Productivity.” Manuscript, 2001.

Baker, George, Michael Gibbs, and Bengt Holmstrom. 1994. "The Internal Economics of the Firm: Evidence From Personnel Data.” Quarterly Journal of Economics 109, 881-919.

Barnett, William P., James N. Baron, and Toby E. Stuart. 2000. "Avenues of Attainment: Occupational Demography and Organizational Careers in the California Public Service." American Journal of Sociology 106, 88-144.

Becker, Gary S. 1962. "Investment in Human Capital: A Theoretical Analysis.” Journal of Political Economy 70, 9-49.

Chan, William. 1996. "External Recruitment versus Internal Promotion." Journal of Labor Economics 14, 555-570.

Doeringer, Peter, and Michael Piore. 1971. Internal Labor Markets and Manpower Analysis. Lexington, MA: D.C. Heath and Company.

Gibbs, Michael. 1995. "Incentive Compensation in a Corporate Hierarchy." Journal of Accounting and Economics 19, 247-277.

Gibbs, Michael, Kathryn Ierulli and Eva M. Meyersson Milgrom. “Occupational Labor Markets.” Manuscript, 2002.

Hall, Robert E. 1982. "The Importance of Lifetime Jobs in the U.S. Economy." American Economic Review 72, 716-24

Holmlund, Bertil and Donald Storrie. 2002. "Temporary Work in Turbulent Times: The Swedish Experience.” Economic Journal 112, F245-F269.

Jovanovic, Boyan. 1979. "Job Matching and the Theory of Turnover.” Journal of Political Economy 87, 1246-60.

Lazear, Edward P. 1979. “Why Is There Mandatory Retirement?” Journal of Political Economy 87, 1261-1284.

Lazear, Edward P. 1992. The Job as a Concept." In William J. Bruns, ed. Performance Measurement, Evaluation, and Incentives. Boston: Harvard Business School Press.

Lazear, Edward P. 2003. "Firm-Specific Human Capital: A Skills-Weight Approach.” Cambridge, MA: NBER Working Paper \#9679.

Lazear, Edward P. and Sherwin Rosen. 1981. "Rank-order Tournaments as Optimum Labor Contracts." Journal of Political Economy 89, 841-864.

Lindbeck, Assar, and Snower, Dennis J. 1986. "Wage Setting, Unemployment, and Insider-Outsider Relations.” American Economic Review 76, 235-39.

Manning, Alan. 2003. Monopsony in Motion. Princeton, NJ: Princeton University Press.

Meyersson Milgrom, Eva M., Trond Petersen, and Vemond Snartland. 2001. "Equal Pay for Equal 
Work? Evidence from Sweden and a Comparison with Norway and the U.S." Scandinavian Journal of Economics 103, 559-583.

Reder, Melvin. 1995. "Theory of Occupational Wage Differentials." American Economic Review $45,833-852$.

Rosen, Sherwin. 1974. "Hedonic Prices and Implicit Markets: Product Differentiation in Pure Competition.” Journal of Political Economy 82, 34-55.

Smith, Adam. 1776. An Inquiry into the Nature and Causes of the Wealth of Nations.

Waldman, Michael. 1984. "Job Assignments, Signalling, and Efficiency." RAND Journal of Economics 15, 255-267. 


\section{Table 1}

\section{Panel A: Proportion in a Level who Moved into that Level Internally}

\begin{tabular}{|c|c|c|c|c|c|c|c|c|}
\hline \multirow[b]{2}{*}{ Level } & \multicolumn{3}{|c|}{ Total \# of Levels } & \multirow[b]{2}{*}{3} & \multirow[b]{2}{*}{4} & \multirow[b]{2}{*}{5} & \multirow[b]{2}{*}{6} & \multirow[b]{2}{*}{7} \\
\hline & & 1 & 2 & & & & & \\
\hline & 1 & $32.00 \%$ & $29.83 \%$ & $29.57 \%$ & $27.01 \%$ & $23.85 \%$ & $25.54 \%$ & $24.19 \%$ \\
\hline & 2 & & $51.81 \%$ & $54.14 \%$ & $50.75 \%$ & $41.81 \%$ & $35.83 \%$ & $32.08 \%$ \\
\hline & 3 & & & $67.21 \%$ & $68.55 \%$ & $65.47 \%$ & $64.72 \%$ & $33.78 \%$ \\
\hline & 4 & & & & $76.10 \%$ & $79.96 \%$ & $80.38 \%$ & $65.25 \%$ \\
\hline & 5 & & & & & $79.65 \%$ & $86.33 \%$ & $84.11 \%$ \\
\hline & 6 & & & & & & $86.90 \%$ & $85.46 \%$ \\
\hline & 7 & & & & & & & $85.19 \%$ \\
\hline
\end{tabular}

\section{Sample Sizes}

Level

$\begin{array}{rrrrrrrr} & 1 & 2 & 3 & 4 & 5 & 6 & 7 \\ \mathbf{1} & 3,019 & 2,665 & 3,534 & 2,888 & 2,210 & 1,163 & 215 \\ \mathbf{2} & & 2,239 & 4,010 & 6,414 & 7,000 & 6,300 & 1,275 \\ \mathbf{3} & & & 2,461 & 4,839 & 9,295 & 14,486 & 7,036 \\ \mathbf{4} & & & & 2,247 & 4,397 & 12,445 & 16,315 \\ \mathbf{5} & & & & & 1,676 & 5,075 & 10,044 \\ \mathbf{6} & & & & & & 1,389 & 3,094 \\ \mathbf{7} & & & & & & & 648 \\ & & & & & & & \\ & 2,086 & 1,461 & 1,464 & 1,124 & 699 & 331 & 102\end{array}$

Employee levels and the number of levels in firm based on 1988. Employees whose 1988 level is the same as their level when the firm first enters the dataset are dropped. 


\section{Table 1}

Panel B: Proportion in a Job/Wage Level who Moved into that Level Internally

\begin{tabular}{|c|c|c|c|c|c|c|}
\hline \multicolumn{7}{|c|}{ Total \# of Job/Wage Levels } \\
\hline Job/Wage & & 1 & 2 & 3 & 4 & 5 \\
\hline \multicolumn{7}{|l|}{ Level } \\
\hline & 1 & $39.87 \%$ & $40.41 \%$ & $38.48 \%$ & $35.80 \%$ & $42.49 \%$ \\
\hline & 2 & & $56.88 \%$ & $57.01 \%$ & $54.92 \%$ & $51.21 \%$ \\
\hline & 3 & & & $70.81 \%$ & $73.63 \%$ & $74.10 \%$ \\
\hline & 4 & & & & $80.79 \%$ & $88.02 \%$ \\
\hline & 5 & & & & & $88.49 \%$ \\
\hline
\end{tabular}

Sample Sizes

Job/Wage

$\begin{array}{lllll}1 & 2 & 3 & 4 & 5\end{array}$

Level

$\begin{array}{rrrrrr}\mathbf{1} & 3,737 & 3,180 & 3,966 & 3,008 & 5,396 \\ \mathbf{2} & & 2,421 & 4,392 & 7,134 & 22,105 \\ \mathbf{3} & & & 2,580 & 4,798 & 45,416 \\ \mathbf{4} & & & & 2,186 & 28,213 \\ \mathbf{5} & & & & & 9,705 \\ & & & & & \\ & 3,568 & 1,708 & 1,444 & 957 & 722\end{array}$

"Job/Wage Level" is defined by taking the average wage of all employees in a given job as of 1988 and then dividing these jobs into five quintiles based on this average wage. "Job/Wage level" of 1 indicates the job is in the bottom quintile of average wages, 2 is the second quintile, etc. Proportion in top part of table is the proportion of people in a Job/Wage Level as of 1988 whose first job at their 1988 employer was in a different Job/Wage Level. Employees for whom it is not clear if their 1988 job was their first at a given employer were dropped. 


\section{Table 2}

\section{Ratio of Number Hired Into Level to Number Currently In Level}

\begin{tabular}{|c|c|c|c|c|c|c|c|c|c|c|c|}
\hline \multirow[t]{2}{*}{ Level } & \multicolumn{2}{|c|}{ Median } & \multirow{2}{*}{$\begin{array}{r}\text { Mean } \\
2.96\end{array}$} & \multicolumn{2}{|c|}{$\begin{array}{l}\text { Firm/level } \\
\text { cells Avg/cell }\end{array}$} & \multirow{2}{*}{$\begin{array}{r}\text { Total } \\
\text { Hired }\end{array}$} & \multirow{2}{*}{$\begin{array}{r}\text { Total } \\
\text { in } \\
\text { Level } \\
4,010\end{array}$} & \multirow{2}{*}{$\begin{array}{c}\text { Cum } \\
\text { Hired } \\
10,582\end{array}$} & \multicolumn{2}{|c|}{$\begin{array}{l}\text { Cum Cum } \\
\text { Empl Hire \% }\end{array}$} & \multirow{2}{*}{$\begin{array}{r}\text { Cum } \\
\text { Employ } \\
\text { \% } \\
0.066\end{array}$} \\
\hline & 1 & 2.00 & & 512 & 7.83 & & & & 4,0 & 0.175 & \\
\hline & 2 & 1.29 & 1.60 & 492 & 30.54 & 25,096 & 15,028 & 35,678 & 19,0 & 0. & 0.314 \\
\hline & 3 & 0.76 & 0.83 & 493 & 50.31 & 18,270 & 24,805 & 53,948 & 43,843 & 0.890 & 0.723 \\
\hline & 4 & 0.50 & 0.56 & 451 & 27.22 & 5,014 & 12,277 & 58,962 & 56,120 & 0.973 & 0.926 \\
\hline & 5 & 0.40 & 0.46 & 512 & 8.78 & 1,651 & 4,493 & 60,613 & 60,613 & 1.000 & 1.000 \\
\hline
\end{tabular}

Total $\quad 0.95 \quad 1.30 \quad 2460 \quad 24.64 \quad 60,613 \quad 60,613$

Sample is limited to employees for whom their job when they first began working for their 1988 employer is available. Those $42 \%$ of the 1988 sample employees who were hired before their firm enters the sample are dropped. The two highest levels are combined into level 5 and the two lowest into level 1. Firms that did not have employees at both levels 1 and 5 in 1988 are dropped. "Median" is the median across all firms at a given level of (\# employees currently at the firm who started at the firm in that level)/(\# in the level at the firm in 1988). "Mean" is the average across all firms of this same ratio. 


\section{Table 3}

\section{Entry Level by Current Level}

Panel A: All employees, level changes only

\begin{tabular}{rrrrrrrrr} 
& \multicolumn{8}{c}{ Entry Level } \\
1988 Level & & $\mathbf{1}$ & $\mathbf{2}$ & $\mathbf{3}$ & $\mathbf{4}$ & $\mathbf{5}$ & Unknown & Total \\
& $\mathbf{1}$ & 4,257 & 325 & 31 & 0 & 0 & 1,626 & 6,239 \\
$\mathbf{2}$ & 4,006 & 12,469 & 519 & 35 & 2 & 7,868 & 24,899 \\
$\mathbf{3}$ & 2,852 & 11,333 & 12,987 & 336 & 26 & 18,941 & 46,475 \\
$\mathbf{4}$ & 703 & 3,183 & 5,358 & 3,832 & 167 & 14,503 & 27,746 \\
$\mathbf{5}$ & 102 & 510 & 1,247 & 1,275 & 1,583 & 5,989 & 10,706 \\
& & & & & & & \\
Total & 11,920 & 27,820 & 20,142 & 5,478 & 1,778 & 48,927 & 116,065
\end{tabular}

Summary: Lower triangle, 45.5\%; Diagonal, 52.3\%, Upper triangle, 2.1\%

Panel B: All employees, level and occupation changes

\begin{tabular}{|c|c|c|c|c|c|c|c|c|}
\hline \multirow[b]{2}{*}{1988 Level } & \multicolumn{4}{|c|}{ Entry Level } & \multirow[b]{2}{*}{5} & \multirow[b]{2}{*}{ Unknown } & \multirow[b]{2}{*}{$\begin{array}{l}\text { Different } \\
\text { Occupat. }\end{array}$} & \multirow[b]{2}{*}{ Total } \\
\hline & 1 & 2 & 3 & 4 & & & & \\
\hline 1 & 3,548 & 99 & 2 & 0 & 0 & 698 & 1,892 & 6,239 \\
\hline 2 & 2,439 & 10,727 & 222 & 12 & 1 & 4,168 & 7,330 & 24,899 \\
\hline 3 & 1,384 & 7,788 & 10,827 & 152 & 6 & 10,217 & 16,101 & 46,475 \\
\hline 4 & 238 & 1,620 & 3,323 & 3,144 & 83 & 6,952 & 12,386 & 27,746 \\
\hline 5 & 20 & 189 & 569 & 748 & 1,271 & 2,495 & 5,414 & 10,706 \\
\hline Total & 7,629 & 20,423 & 14,943 & 4,056 & 1,361 & 24,530 & 43,123 & 116,065 \\
\hline
\end{tabular}

Summary: Lower triangle, 37.8\%; Diagonal, 61.0\%, Upper triangle, 1.2\% 
Table 3 (cont.)

Panel C: Employees with ten years or more service, level changes only

\begin{tabular}{|c|c|c|c|c|c|c|c|}
\hline \multirow{2}{*}{$\begin{array}{l}\text { Current } \\
\text { Level }\end{array}$} & \multicolumn{4}{|c|}{ Entry Level } & \multirow{2}{*}{\multicolumn{2}{|c|}{5 Unknown }} & \multirow{3}{*}{$\begin{array}{l}\text { Total } \\
2,162\end{array}$} \\
\hline & 1 & 2 & 3 & 4 & & & \\
\hline 1 & 835 & 161 & 16 & 0 & 0 & 1,150 & \\
\hline 2 & 1,467 & 2,349 & 215 & 20 & 1 & 4,879 & 8,931 \\
\hline 3 & 1,562 & 3,916 & 2,160 & 138 & 17 & 12,286 & 20,079 \\
\hline 4 & 505 & 1,759 & 2,089 & 756 & 92 & 10,455 & 15,656 \\
\hline 5 & 83 & 348 & 789 & 602 & 465 & 4,625 & 6,912 \\
\hline Total & 4,452 & 8,533 & 5,269 & 1,516 & 575 & 33,395 & 53,740 \\
\hline
\end{tabular}

Summary: Lower triangle, 64.5\%; Diagonal, 32.3\%, Upper triangle, 3.2\%

Notes to all panels: The two highest levels are combined into level 5 and the two lowest into level 1. Firms that did not have employees at both levels 1 and 5 in 1988 are dropped. 
Table 4

\section{Job Tenure by Level}

\begin{tabular}{|c|c|c|c|c|c|c|c|c|c|c|}
\hline \multirow[b]{2}{*}{ Level } & \multicolumn{2}{|c|}{ All Observ. } & \multicolumn{2}{|c|}{ Uncensored } & \multicolumn{2}{|c|}{ Left Censored } & \multicolumn{2}{|c|}{ Right Censored } & \multicolumn{2}{|c|}{$\begin{array}{c}\text { Both Sides } \\
\text { Censored }\end{array}$} \\
\hline & Mean & \# obs & Mean & \# obs & Mean & \# obs & Mean & \# obs & Mean & \# obs \\
\hline $\mathbf{1}$ & 1.85 & 117,688 & 1.63 & 77,735 & 1.94 & 22,805 & 2.64 & 14,891 & 3.02 & 2,257 \\
\hline 2 & 2.66 & 291,391 & 2.25 & 181,325 & 2.99 & 50,219 & 3.46 & 52,110 & 4.79 & 7,737 \\
\hline 3 & 3.22 & 343,097 & 2.87 & 205,814 & 3.52 & 45,444 & 3.70 & 82,159 & 5.40 & 9,680 \\
\hline 4 & 3.44 & 174,643 & 3.08 & 101,247 & 3.70 & 21,063 & 3.85 & 47,568 & 5.90 & 4,765 \\
\hline 5 & 3.32 & 69,601 & 3.00 & 41,425 & 3.39 & 8,631 & 3.88 & 17,667 & 4.85 & 1,878 \\
\hline Total & 2.94 & 996,420 & 2.56 & 607,546 & 3.12 & 148,162 & 3.61 & 214,395 & 5.07 & 26,317 \\
\hline
\end{tabular}

$\begin{array}{rrrr}\text { Level } & \begin{array}{r}\text { \% right } \\ \text { cens }\end{array} & \begin{array}{r}\text { \% left } \\ \text { cens }\end{array} \\ \mathbf{1} & 14.57 \% & 21.30 \% \\ \mathbf{2} & 20.54 \% & 19.89 \% \\ \mathbf{3} & 26.77 \% & 16.07 \% \\ \mathbf{4} & 29.97 \% & 14.79 \% \\ \mathbf{5} & 28.08 \% & 15.10 \%\end{array}$

Total $\quad 24.16 \% \quad 17.51 \%$

Mean job tenure is average number of years in the specific job (that is, occupation/level combination).

\section{Censoring Methodology:}

The two highest levels are combined into level 5 and the two lowest into level 1. Firms that did not have employees at both levels 1 and 5 at some point while in the sample are dropped. An observation is an individual spell of employment in one level at one firm. A job is "left censored" if the employee was working in that job in the first year in which his firm was in the available dataset. A job is "right censored" if the employee was working in that job in the last year in which his firm was in the available dataset. 


\section{Table 5}

Job Entry and Job Exit Rates by Level

\section{Panel A: Full Sample}

\begin{tabular}{rrrrrrr} 
Level & \multicolumn{8}{l}{$\begin{array}{l}\text { External Internal External Internal } \\
\text { Entry }\end{array}$} & $\begin{array}{l}\text { Entry } \\
\text { Exit }\end{array}$ & Exit & Observations \\
& $\mathbf{1}$ & $22.45 \%$ & $9.24 \%$ & $12.29 \%$ & $20.41 \%$ & 276,102 \\
$\mathbf{2}$ & $15.44 \%$ & $9.95 \%$ & $9.52 \%$ & $14.83 \%$ & 874,621 \\
$\mathbf{3}$ & $10.03 \%$ & $13.03 \%$ & $8.79 \%$ & $10.75 \%$ & $1,179,978$ \\
$\mathbf{4}$ & $6.90 \%$ & $15.47 \%$ & $8.63 \%$ & $9.37 \%$ & 624,829 \\
$\mathbf{5}$ & $6.72 \%$ & $15.78 \%$ & $10.49 \%$ & $8.27 \%$ & 245,274 \\
& & & & & \\
& Total & $11.72 \%$ & $12.55 \%$ & $9.39 \%$ & $12.24 \%$ & $3,200,804$
\end{tabular}

Panel B: Employers between 40 and 45 Years Old

\begin{tabular}{|c|c|c|c|c|c|c|}
\hline \multirow{7}{*}{ Level } & \multicolumn{3}{|c|}{ External Internal } & \multicolumn{2}{|c|}{ External Internal } & \multirow[b]{2}{*}{ Observations } \\
\hline & & try & Entry & Exit & Exit & \\
\hline & 1 & $8.50 \%$ & $9.82 \%$ & $8.09 \%$ & $12.96 \%$ & 86,785 \\
\hline & 2 & $6.59 \%$ & $7.73 \%$ & $6.79 \%$ & $9.89 \%$ & 333,454 \\
\hline & 3 & $5.03 \%$ & $9.23 \%$ & $6.78 \%$ & $8.07 \%$ & 525,140 \\
\hline & 4 & $4.50 \%$ & $10.73 \%$ & $7.18 \%$ & $7.93 \%$ & 349,696 \\
\hline & 5 & $5.10 \%$ & $11.91 \%$ & $9.53 \%$ & $7.55 \%$ & 172,344 \\
\hline & & $5.47 \%$ & $9.60 \%$ & $7.28 \%$ & $8.68 \%$ & $1,467,419$ \\
\hline
\end{tabular}

An observation is a person/year. An observation is defined as an "external entry" if the person is not working at the firm in year $t$ and works at the firm in a given job in year $t+1$. The other entry and exit variables are defined similarly. The first and last year that any firm is in the dataset is dropped from the sample. 


\section{Table 6}

\section{Analysis of Variance - Internal Entry Rate}

Dependent Variable $=$ Fraction of workers in a job at a firm that moved to that job from another job at the same firm

\section{Panel A: Firms and Jobs}

\begin{tabular}{lccc} 
Type of Indicator & \# of Indicators & $\begin{array}{c}\text { Partial Sum of } \\
\text { Squares }\end{array}$ & P-value \\
\hline \hline Firm & 100 & 35.68 & 0.000 \\
Jobs & 252 & 198.30 & 0.000 \\
\hline Total & & 753.31 &
\end{tabular}

Regression of internal movement rate for 6,306 firm $/$ job combinations. R-square $=31.88 \%$. Sample includes white-collar workers at 100 largest firms in SAF dataset. An observation is a firm/job in 1988.

\section{Panel B: Firms, Levels, and Occupation Groups}

Type of Indicator \# of Indicators Partial Sum of P-value

Squares

\begin{tabular}{lccc}
\hline \hline Firm & 100 & 36.51 & 0.000 \\
Occupation & 51 & 40.55 & 0.000 \\
Level & 5 & 85.26 & 0.000 \\
\hline
\end{tabular}

Total

753.31

Regression of internal movement rate for 6,306 firm/job combinations. R-square $=23.86 \%$. Sample includes white-collar workers at 100 largest firms in SAF dataset. An observation is a firm/job in 1988. 


\section{Table 7}

\section{Analysis of Variance}

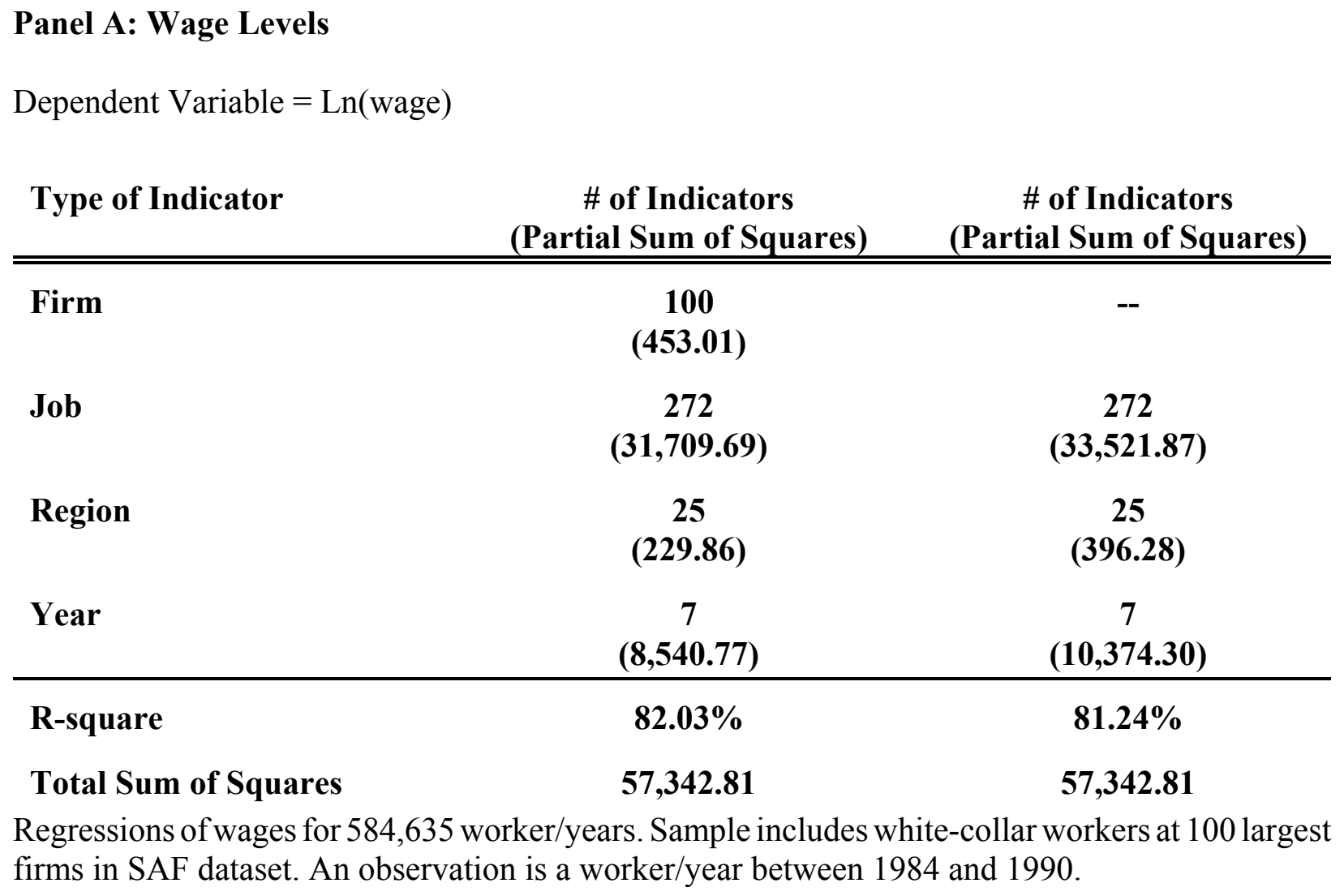


Table 7 (cont.)

\begin{tabular}{|c|c|c|}
\hline \multicolumn{3}{|c|}{$\begin{array}{l}\text { Panel B: Wage Changes } \\
\text { Dependent Variable = Change in Ln(wage) from previous year }\end{array}$} \\
\hline Type of Indicator & $\begin{array}{c}\text { \# of Indicators } \\
\text { (Partial Sum of Squares) } \\
\end{array}$ & $\begin{array}{c}\text { \# of Indicators } \\
\text { (Partial Sum of Squares) } \\
\end{array}$ \\
\hline Firm & $\begin{array}{c}97 \\
(\mathbf{2 4 . 3 6 )}\end{array}$ & - \\
\hline Job & 272 & 268 \\
\hline Region & 25 & 25 \\
\hline Year & $\begin{array}{c}6 \\
(76.98)\end{array}$ & $\begin{array}{c}6 \\
(84.15) \\
\end{array}$ \\
\hline R-square & $10.85 \%$ & $9.14 \%$ \\
\hline Total Sum of Squares & $1,429.49$ & $1,429.49$ \\
\hline
\end{tabular}

Regression of wages for 415,606 worker/years. Sample includes white-collar workers at the 97 of the 100 largest firms in SAF dataset for which wage change data is available. An observation is a worker/year between 1985 and 1990 . 
Figure 1

\section{Identification of Labor Market Fluidity}

\begin{tabular}{|c|c|c|c|}
\hline & & \multicolumn{2}{|l|}{ Hiring at higher levels of firm } \\
\hline & & Substantial External Hiring & Primarily Internal Hiring \\
\hline \multirow[t]{2}{*}{$\begin{array}{l}\text { Wage } \\
\text { Movements }\end{array}$} & $\begin{array}{l}\text { Move } \\
\text { together }\end{array}$ & External labor market & $\begin{array}{l}\text { Consistent with both spot and } \\
\text { internal labor market }\end{array}$ \\
\hline & $\begin{array}{l}\text { Movement is } \\
\text { idiosyncratic }\end{array}$ & $\begin{array}{l}\text { Inconsistent with both spot } \\
\text { and internal labor markets }\end{array}$ & Internal labor market \\
\hline
\end{tabular}


Figure 2

Number of Workers by Level

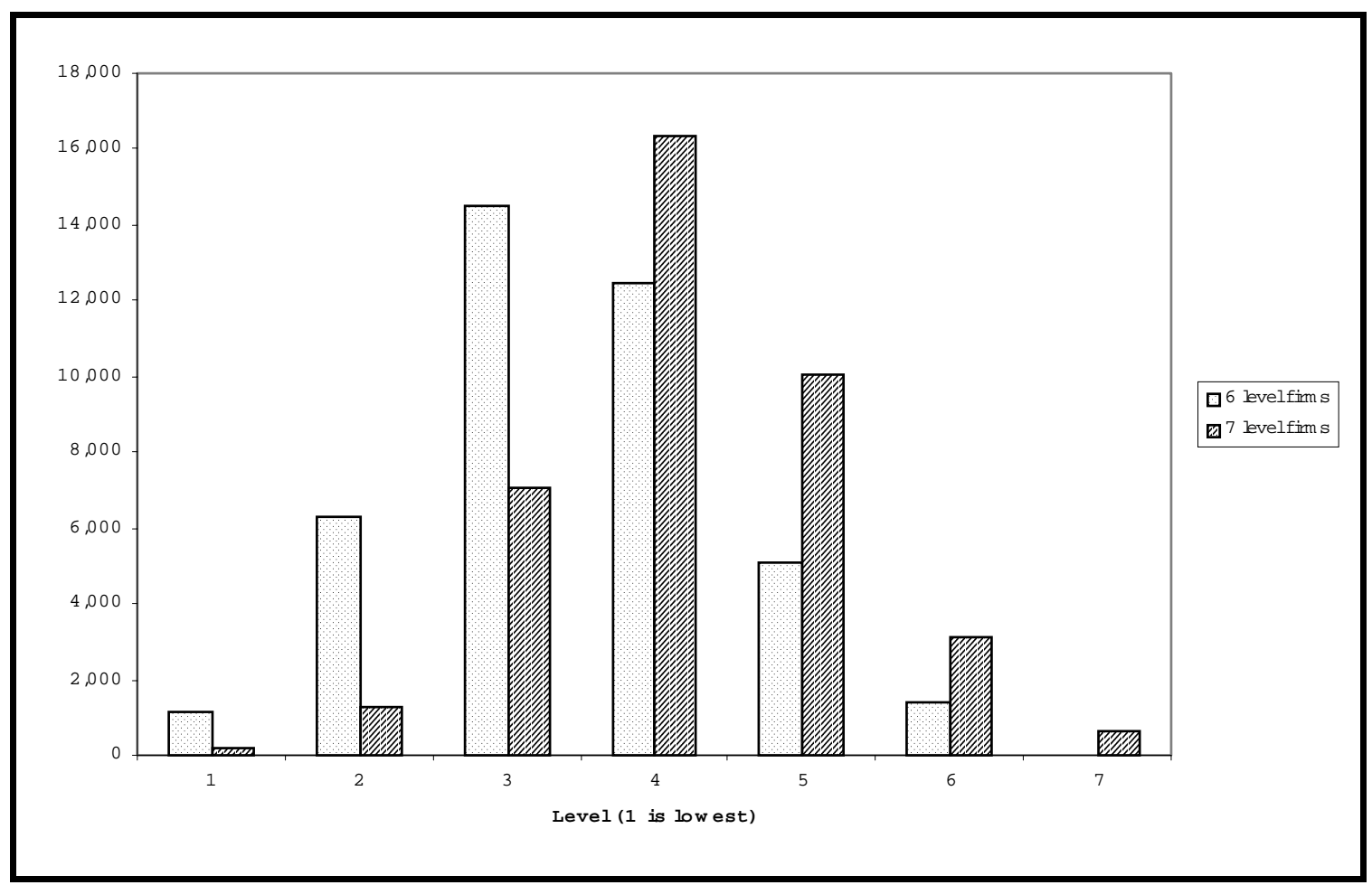


Figure 3

\section{Cumulative Wage Distribution}

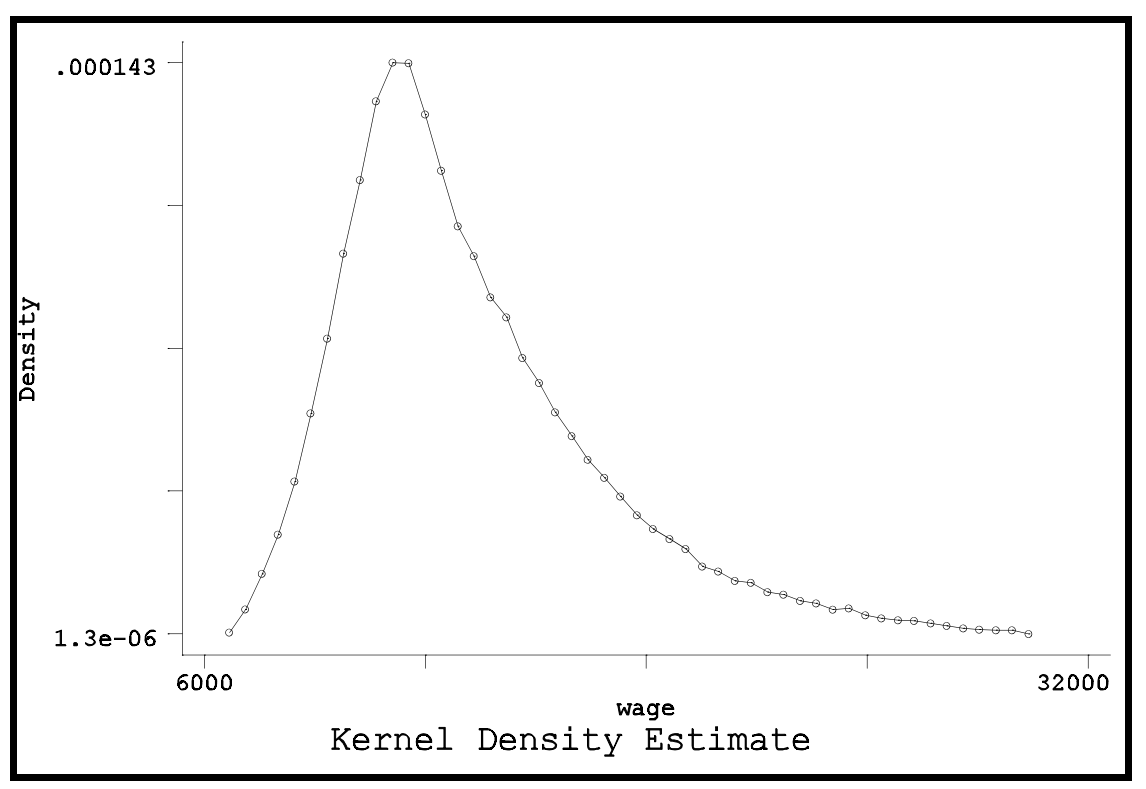

Sample includes all employees in 1988. Wage is Swedish Kroners per month. 
Figure 4

Wage Distribution at Largest Firm

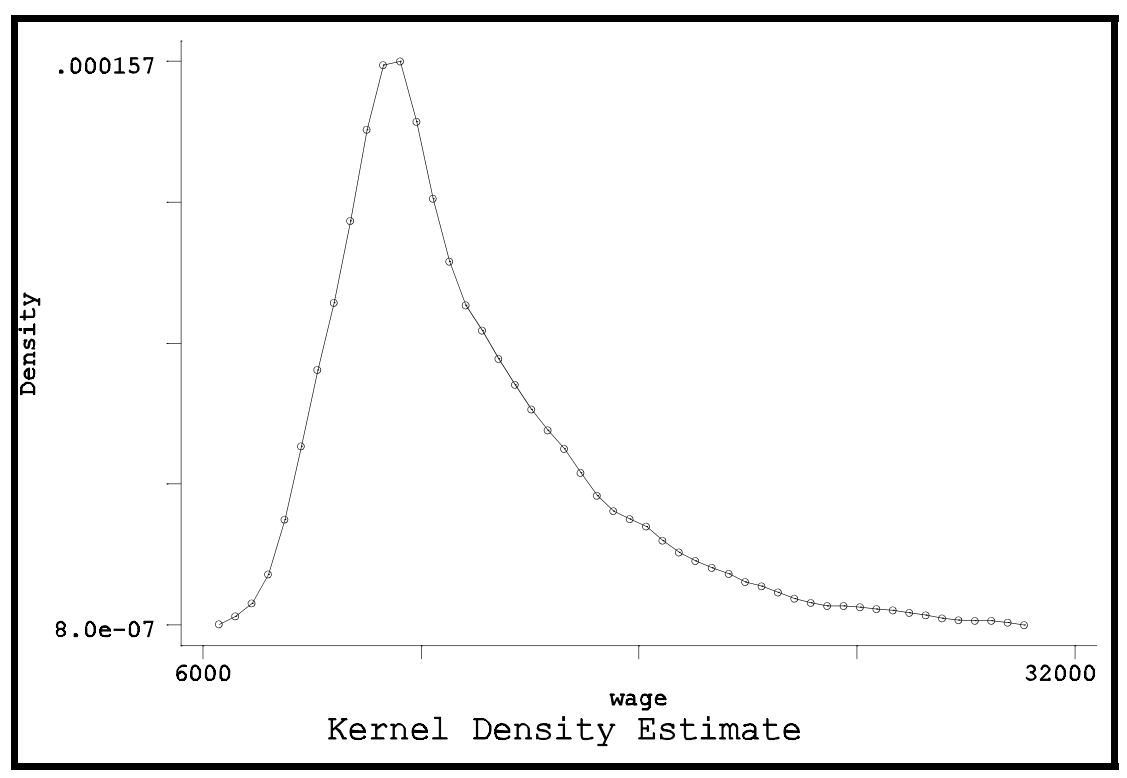

Sample includes 7417 employees of a single firm in 1988. 
Figure 5

Wage Distribution of Construction Occupation

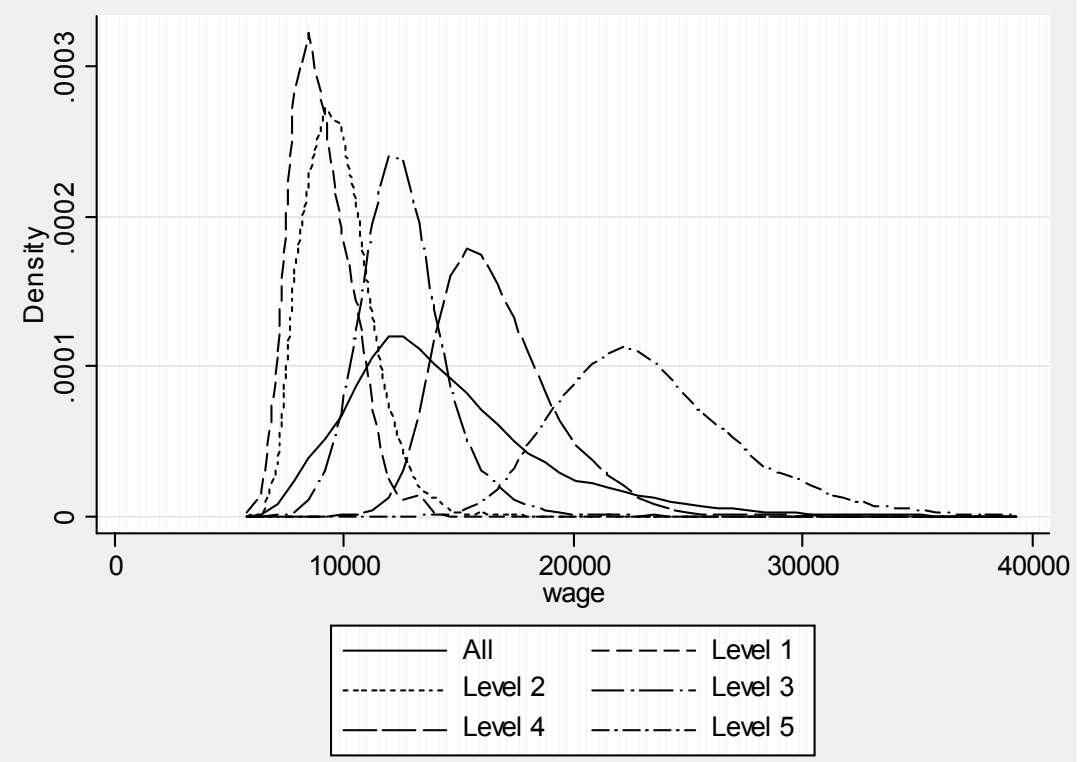

Figure 5A: Wage Levels

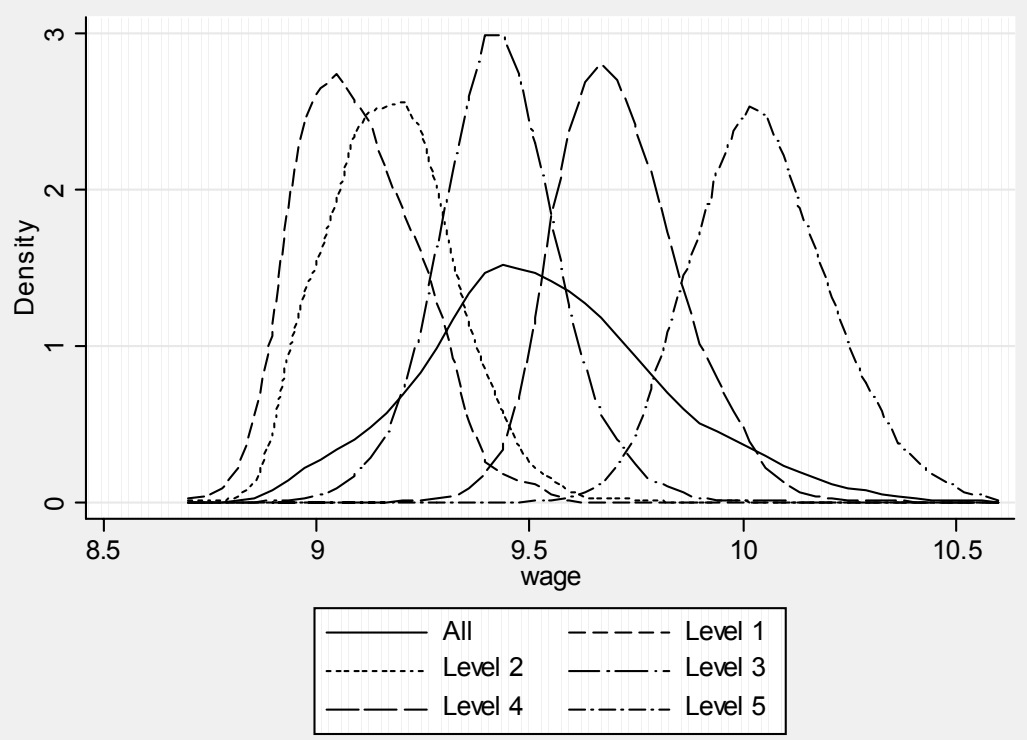

Figure 5B: Log Wages 


\section{Appendix \\ Description of Positions in SAF Data}

Occupation Family 1: Occupation \# 120 - Manufacturing, Repair, Maintenance, and Transportation

$11 \%$ of 1988 sample

There is no level 1 in this occupation.

Level 2 (4\% of occupation \#120 employees) - Assistant for unit; insures instructions are followed; monitors processes

Level $3(46 \%)$ - In charge of a unit of 15-35 people

Level $4(45 \%)$ - In charge of 30-90 people; does investigations of disruptions and injuries

Level $5(4 \%)$ - In charge of 90-180 people; manages more complicated tasks

Level $6(0.3 \%)$ - Manages 180 or more people

There is no level 7 in this occupation.

Occupation Family 2: Occupation \#310 - Construction

$10 \%$ of the 1988 sample

Level $1(0.1 \%)$ - Cleans sketches; writes descriptions

Level $2(1 \%)$ - Does more advanced sketches

Level $3(12 \%)$ - Simple calculations regarding dimensions, materials, etc.

Level 4 (45\%) - Chooses components; does more detailed sketches and descriptions; estimates costs

Level $5(32 \%)$ - Designs mechanical products and technical products; does investigations; has 3 or more subordinates at lower levels

Level $6(8 \%)$ - Executes complex calculations; checks materials; leads construction work; has 3 or more subordinates at level 5

Level 7 (1\%) - Same as level 6 plus has 2-5 level 6 subordinates

Occupation Family 3: Occupation \#800 - Marketing and Sales

$19 \%$ of 1988 sample

Level $1(0.2 \%)$ - Telesales; expedites invoices; files

Level $2(6 \%)$ - Puts together orders; distributes price and product information

Level $3(29 \%)$ - Seeks new clients for 1-3 products; can sign orders; does market surveys

Level $4(38 \%)$ - Sells more and more complex products; negotiates bigger orders; manages 3 or more subordinates

Level $5(20 \%)$ - Manages budgets; develops products; manages 3 or more level 4 workers

Level $6(7 \%)$ - Organizes, plans, and evaluates salesforce; does more advanced budgeting; manages 3 or more level 5 workers

Level $7(1 \%)$ - Same as level 6 plus 2-5 level 6 subordinates

Occupation Family 4: Occupation \#900 - Finance

$5 \%$ of 1988 sample

Level 1 (1\%) - Office work; bookkeeping; invoices; bank verification

Level $2(7 \%)$ - Manages petty cash; calculates salaries

Level 3 (18\%) - More advanced accounting; 4-10 subordinates

Level 4 (31\%) - Places liquid assets; manages lenders; evaluates credit of buyers; manages 3 or more level 3 employees

Level 5 (28\%) - Financial planning; analyzes markets; manages portfolios; currency transfers; manages 3 or more level 4 employees

Level $6(12 \%)$ - Manages credits; plan routines within the organization; forward-looking budgeting; manages 3 or more level 5 employees

Level 7 (2\%) - Same as level 6 plus 2-5 level 6 subordinates 